\title{
Adoption of Conservation Agriculture in Rwanda: A Case Study of Gicumbi District Region
}

\author{
Yves Theoneste Murindangabo *(D), Marek Kopecký (D) and Petr Konvalina \\ Department of Agroecosystems, University of South Bohemia in Ceske Budejovice, Branišovská 1645/31a, \\ 37005 Ceske Budejovice, Czech Republic; mkopecky@zf.jcu.cz (M.K.); konvalina@zf.jcu.cz (P.K.) \\ * Correspondence: muriny00@jcu.cz
}

Citation: Murindangabo, Y.T.; Kopecký, M.; Konvalina, P. Adoption of Conservation Agriculture in Rwanda: A Case Study of Gicumbi District Region. Agronomy 2021, 11, 1732. https://doi.org/10.3390/ agronomy11091732

Academic Editor: Carlos Cantero-Martínez

Received: 4 August 2021

Accepted: 26 August 2021

Published: 29 August 2021

Publisher's Note: MDPI stays neutral with regard to jurisdictional claims in published maps and institutional affiliations.

Copyright: (c) 2021 by the authors. Licensee MDPI, Basel, Switzerland. This article is an open access article distributed under the terms and conditions of the Creative Commons Attribution (CC BY) license (https:// creativecommons.org/licenses/by/ $4.0 /)$.

\begin{abstract}
Conservation agriculture (CA) is described as a farming system that is founded around three principles: minimum soil disturbance (reduced or no tillage), keeping a permanent soil cover (with crop residues, cover crops or both) and plant species diversification (plant associations and sequences). Little to no information has been documented about conservation agriculture adoption in developing countries, such as Rwanda, with especially no information about its hilly and climatevarying part to which the Gicumbi district belongs. This study is targeted towards ascertaining the level of CA adoption in the Gicumbi district in relation to the socioeconomic status of the farming population, to suggest the relevant strategies for accelerating CA adoption specific to this region. The sampling technique used was a non-discriminative, snowball-sampling one, eventually gathering data from 500 households in three sectors. Semi-structured interviews were conducted using household questionnaires. Adoption of CA was related to the knowledge acquired during training and hands-on work on demonstration plots. Some farm-level constraints found were little to no material, few extension services and market problems. The impacts attributed to the use of CA were soil and productivity improvement.
\end{abstract}

Keywords: conservation agriculture; farmer's perception; adoption; socioeconomic; minimum soil disturbance; crop rotation

\section{Introduction}

The demographic profile of Rwanda is distinguished by a high population growth with a dominating number of youths. The total number of the population has doubled from 4.8 to 10.5 million people between 1978 and 2012, and is further expected to increase to 15.7 million in 2030, and to 26.8 million in 2070, bringing about a remarkably high population density of 415 per square kilometer [1,2]. This has contributed to an increasing dependency ratio and inevitably a high pressure on the available livelihood resources, employment, economic development, family welfare as well as environmental constraints. Another key feature of this demography is that the economic growth is driven by the service sector, contributing $48 \%$ of the GDP, followed by agriculture with $31 \%[3,4]$, which also still employing more than two thirds of the work force $(68 \%)$ [5].

Rwandan agriculture is sustained by poor, less educated smallholder farmers who account for $70 \%$ of the export revenues and $90 \%$ of the national needs, with less than a half hectare each [4]. As far as employment is concerned, the agricultural sector is regarded as one among the first growth sectors with high job-multiplying effects, as it mainly provides livelihoods and forms the biggest household enterprises [5]. However, attempting to increase agricultural yields and food security is compromised by poor agricultural land management and degradation of land, resulting in a poor soil health [6-8]. Soil degradation and losses are among the factors compromising productivity; $48.6 \mathrm{t} \mathrm{ha}^{-1} \mathrm{y}^{-1}$ and $39.2 \mathrm{t} \mathrm{ha}^{-1} \mathrm{y}^{-1}$ of soil were degraded and lost by water erosion in 2000 and 2015, respectively, leading to a total nationwide loss of approximately 110 and 89 million tons [9]. 
Over the last 15 years, $34.6 \%$ of the total areas of the evaluated land use/land cover types have undergone changes, leading to different degrees of degradation [9]. It is highly expected that climate change will seriously hit the agriculture sector in Africa [10]. This will inevitably have a negative effect on the wellbeing of people in this developing area [11]. Moreover, as the agriculture in this part of the world depends on rain [12], climate variability effects will be more pronounced [12]. For instance, in the highly sloped and drought-prone parts of Rwanda, such as the east and part of the north, poor soil management practices, timing of agricultural operations, frequent erosion, delayed rains, leading to droughts, will continue to lead to significant soil degradation and poor yields [13]. From the above, Rwanda looks vulnerable. Based on the need for sustainable land use, the ministry of agriculture considered CA practices as part of the crop intensification program since 2007 [14], in the strategic plan for agriculture transformation 2018-2024 [15] and in the revised Rwanda agriculture policy [16].

Conservation agriculture is built on disturbing the soil as little as possible, keeping the soil permanently covered with residues from crops or planting cover crops, and rotating and mixing crops [17]. This last one has proven itself a remedy to soil degradation and it is recommended for areas affected by climate variability, whether in high or low rainfall [18-20]. As far as Rwanda is concerned, the northern and western part experience high rainfall, which results in soil degradation and erosion [8], whereas the eastern and southern part of the country experience frequent shortage of rain and crops are often affected by water-related stresses [21].

In this study, we concentrated the CA concept to all three principles, though farmers of this northern part (Gicumbi district) of the country are rarely practicing soil covering or mulching. This research studied the level of practice of these principles in relation to to the socioeconomic status of the population. Apart from the yield increases associated with permanent planting basins on degraded soils [22], CA also presents other benefits, such as, but not limited to, soil and water conservation [23], labor reduction, recovery of degraded fields, improved food security and soil-erosion control [22,24]. Unfortunately, the low adoption of CA in Africa does not yet seem to lead to success, though an increase in African land under CA from 0.3\% [25] to 1.32\% [26] has been reported.

The more the factors influencing non adoption of CA practices and their effects are not well researched or studied on, the more its adoption becomes difficult. Though many studies on CA reveal context-specific constraints, which include, but are not limited to, complexities within African smallholder-farming systems, unfavourable institutional policy approaches [27], lack of appropriate extension [28], limited access to credit and underdeveloped input and output markets [29-31], competition for crop residues for use as animal fodder [32-34], the approach of CA promotion as a package $[18,19,35]$ and the inappropriateness of the technology to the target group [36-38], there are also factors that have enabled farmers to adopt CA, for instance, peer influence, financial status [39-41] and information availability [42].

Nowadays, the focus of developing an agenda is one of the ways of improving the adoption of CA by farmers [26]. Due to country diversity, studies on the reasons for CA uptake and/or the hindering factors that could inform the adoption process are needed [43]. Considering Rwanda, which has twelve agro-ecological zones and cultural diversities, differences in adoption can be expected in terms of gender, costs, location, prior knowledge of farming practices, etc. There should also be studies on the expected profits from practicing CA in different agro-ecological zones, as such information and differences in preferences affect the likelihood of adoption even within the same region.

This study targeted the determination of the level of CA adoption in the Gicumbi sub-region of Rwanda in relation to the socioeconomic status of the farming population and to suggest a relevant strategy for accelerating CA uptake specific to the region. The study gathered the experiences and views of farmers' perceptions on the appropriateness and impact of CA within their context. It identified the underlying factors that caused and/or prevented farmers from taking up this technology. The study area has one of the 
highest poverty rates in the country. The data captured the respondents' estimated use of CA on their land, the frequency of use and their individual reasons for adopting it. Other factors looked at included the economic and social factors, to form a background for further promotion of CA in the region. The data from this study will serve as the baseline for developing this technology in other parts of the country, as CA is almost starting in the country.

\section{Materials and Methods}

\subsection{Description of Study Site}

The Gicumbi district is located in the northern part of Rwanda $\left(1^{\circ} 37^{\prime} \mathrm{S} 30^{\circ} 07^{\prime} \mathrm{E}\right)$. The main economic activities there are centred on crop production and animal rearing. This area is highly mountainous and part of it is among the driest in the country. It experiences two rainy seasons on average, also known as a bimodal rainfall type, in which farmers can grow crops. Even though the Gicumbi district region is prone to erosion and land degradation due to its topography, it is also recognized for its potentiality of being one of the country's grain, milk and banana baskets. Farmers there grow cereals (maize, sorghum, wheat), legumes (beans, peas), banana, vegetables and root tubers (sweet potatoes, Irish potatoes, cassava) on top of rearing cattle and small ruminants, such as swine, poultry, goats and sheep. These provide the staple food for people beyond the region and play a role in income generation for rural households and a substantial contribution to the national economy. The soil type there in the mountains is characterized by lateritic soils and granites that are disintegrative, easily weathered and undergo particle breakage, which makes it environmentally fragile and prone to erosion; however, the high clay content offers the advantage of a higher cation-exchange capacity (CEC) and water-holding capacity, leading to good production [44].

Generally, family members are the main available farm labor who also uses rudimentary materials such as hand hoes for land opening, soil inversion, weeding and other farm activities. Under CA in the region, farmers aim for minimum tillage with hoes by only making permanent planting stations that are done without tilling the land deeply.

\subsection{Data Collection}

Consultative meetings were initiated first with the district administrative headquarters direction of Agriculture and Natural resources, which is in charge of climate-resilient agriculture and natural resources management, followed by a meeting with the partners developing CA in that region. The information gathered and the discussions held led to identifying Gicumbi as a study site because of the need for data on the region. Gicumbi was a major area in northern Rwanda where CA was promoted and supported from July 2016 onwards. Primary data were collected in 2021 over a five-year period from three sub-district locations (sectors), namely, Byumba, Nyamiyaga and Rukomo. In Byumba, data were collected from farmers in the Gashirwe, Kibali and Rwasama cells (villages); in Nyamiyaga, the respondents were chosen from the Kagamba and Mataba cells; and the rest were taken from the Cyuru, Munyinya and Nyinawimana cells in the Rukomo sector.

The snowballing nonprobability sampling technique was used to reach the respondents. The snowball technique involves using a known contact to identify other persons to be considered as subjects in a given study. The method was employed because the area was hard to reach, and information about the respondents was not easily accessible [45]. The face-to-face interviews using a questionnaire started with two females and one male agricultural officers identified as from the local government (sectors). The three sector agronomists, in turn, suggested eight other lead farmers (one per cell/village) to be interviewed. The eight lead farmers suggested the rest of the interviewees in their respective groups and, subsequently, the 500 respondents as shown in Figure 1 and Table 1. The selection of respondents was subjective, in the sense that the predefined group sought was that of farmers that had experienced CA; i.e., those who had practiced it themselves or had received training on it. 


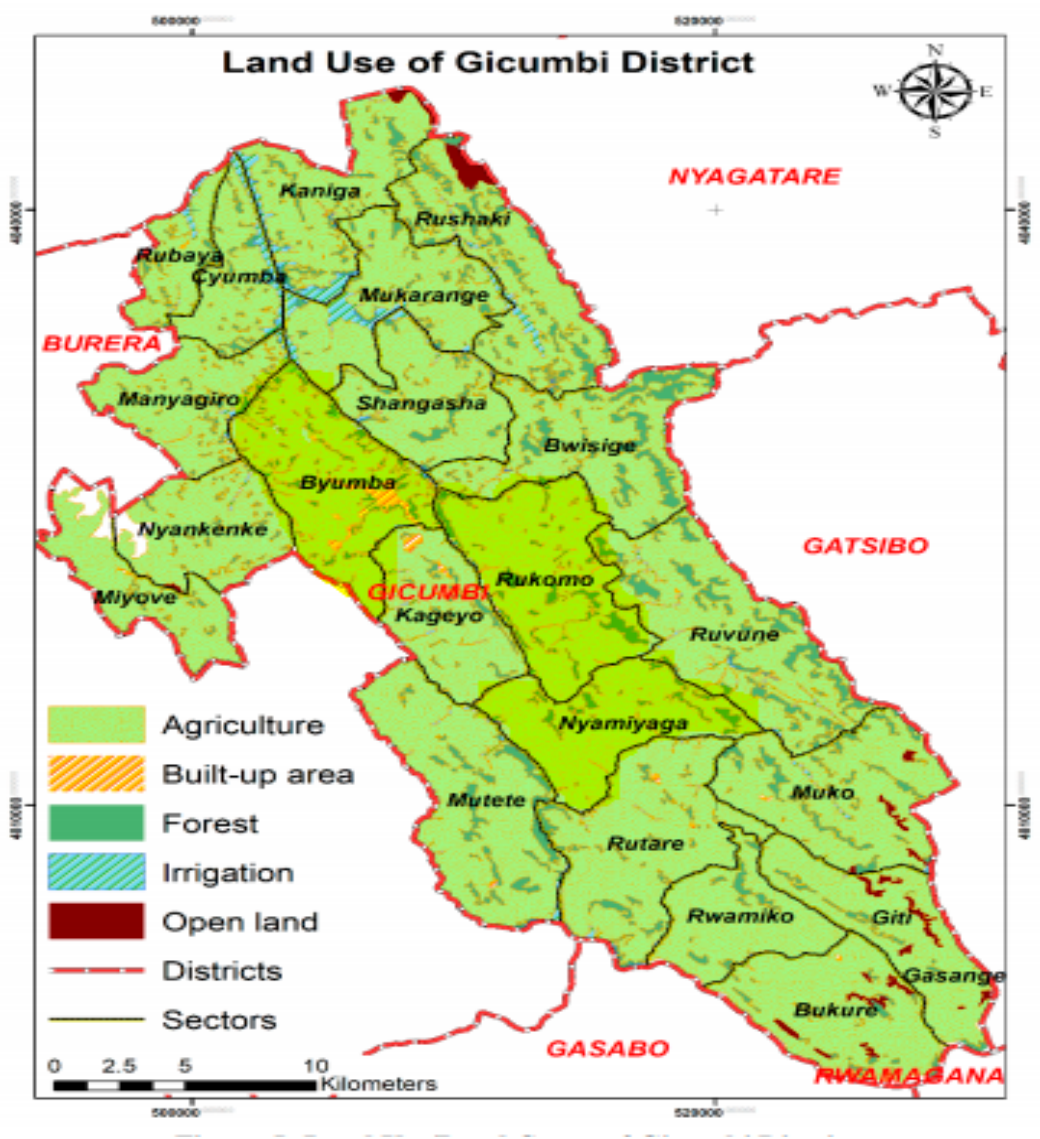

Figure 1. Study locations in the Gicumbi district, Rwanda. Map source: Adapted from Gicumbi District [46].

Table 1. Respondents distribution.

\begin{tabular}{ccc}
\hline Sectors (Sub-Districts) & Cells (Villages) & Respondents \\
\hline Sector agronomists & & 3 \\
\hline Lead farmers & & 8 \\
\hline \multirow{2}{*}{ Byumba } & Gashirwe & 45 \\
& Kibali & 58 \\
& Rwasama & 60 \\
\hline \multirow{2}{*}{ Nyamiyaga } & Kagamba & 79 \\
& Mataba & 84 \\
\hline \multirow{2}{*}{ Rukomo } & Cyuru & 60 \\
& Munyinya & 45 \\
Total & Nyinawimana & 58 \\
\hline
\end{tabular}

The sample was heterogeneous in that it aimed at getting views, opinions and ideas, and not so much proportionately representing the respondents' numbers.

This study used a semi-structured questionnaire that was organized under seven different sections; these had matching questions and were a mix of multiple-choice and open-ended questions, and statements that required ranking. The seven sections were demographic characteristics, farming practices, financial support, CA knowledge, sociocultural issues, economic factors and institutional factors. The section on the sociodemographic characteristics of the respondents included biographical data and a description of the respondents' farming practices. The financial dependence section required information 
on receipt of external funding and sources of finances. The third section required a description of how respondents understood and practiced $\mathrm{CA}$, the frequency of performing $\mathrm{CA}$, explanations of the respondents' CA practices and their estimated amount of land portion under CA. This section also included open-ended questions on community perceptions, benefits and constraints at the farm level and their perceived requirements for increasing CA adoption in their community. This was followed by a section on socioeconomic issues, which, in this case, referred to land ownership, access and control to use the land. They additionally had to rank statements on typical factors that could influence their CA adoption, such as personal decisions, farmer-group dynamics and/or cultural expectations. The section on economic factors allowed respondents to estimate the amount of money that they invested in their venture and evaluate statements that could influence their CA adoption. The final section, on institutional factors, required information on government programs and extension services. The final open-ended question required respondents to give any additional information and/or make recommendations on how CA adoption could be increased in their region as shown in Table 2. The above sections and their subsequent questions were guided by other adoption surveys such as the CIMMYT 1993 survey program and Rapid Appraisal of Agricultural Innovation Systems (RAAIS), which is a diagnostic tool useful in analyzing agricultural problems [47,48].

Table 2. Description of the structure of the questionnaire (interview) and the information needed.

\begin{tabular}{cc}
\hline Sections & Information Needed \\
\hline Demographic characteristics & Biographical data \\
\hline Farming practices & $\begin{array}{c}\text { Existing practices (How do they prepare their land, do they } \\
\text { practice crop rotation and mulch their land, are they using archaic } \\
\text { practices for subsistence or modern market oriented one) }\end{array}$ \\
\hline Financial support & Access to aid or any other external funding \\
\hline CA knowledge & $\begin{array}{c}\text { Understanding of CA, frequency of practicing it, land size } \\
\text { allocated to CA, Community perception of CA, Benefits and } \\
\text { constraints at farm level, Requirements for increased adoption } \\
\text { of CA. }\end{array}$ \\
\hline Sociocultural issues & $\begin{array}{c}\text { Land ownership, Access and control to use the land, personal } \\
\text { decision, Farmer group dynamics, Cultural expectations }\end{array}$ \\
\hline Economic factors & $\begin{array}{c}\text { Amount of money invested in CA, ranking the level of } \\
\text { adoption (ranking statements that could influence their } \\
\text { adoption of this technology like profit expectations, } \\
\text { availability of market, increased yields and available cash, } \\
\text { relying on loans or even donations) }\end{array}$ \\
\hline Institutional factors & $\begin{array}{c}\text { Government programs and extension services related to CA } \\
\text { Additional information }\end{array}$ \\
\hline
\end{tabular}

There has not been any communication barrier as the whole country speaks the same mother language (Kinyarwanda). Information in the coded questionnaires was crosschecked in the field to ensure that questions had fully been understood, responded to and clearly filled in. Information from the open-ended questions was summarized, categorized and coded depending on similarity. Data were initially entered in Excel sheets before analysis using STATISTICA (version 12).

\section{Analysis of Characteristics of CA Adopters}

\subsection{Socio-Demographic Characterization}

A high number of farmers that practiced CA were female, had little education and were mostly married above 30 years of age. Out of the sample population of 500 people, two-thirds were female, and close to $90 \%$ were married. The data showed that respondents households had 5-7 people. These numbers seem a bit higher than the national average 
household size of 4.8 for 5 in this region, as reported in the EICV3 2010/2011 survey. Concerning education, more than $70 \%$ of the respondents only had primary-school-level education as the highest level of education.

\subsection{Farming Practices}

As far as farming practices are concerned, most of the respondents are practicing mixed-farming activities, most of which are for subsistence only. In fact, $90 \%$ of the respondents practiced subsistence farming and sold their surplus to the market, simultaneously getting the possibility to buy other types of food they do not grow themselves. Their household members are the only labor they use.

\subsection{Financial Aspects}

This part deals with whether the respondents were dependent on external funding and, if not, the sources of their finances. All of them used their own savings in their small groups called IBIMINA to finance their farming activities as the partners had taught them. More than $90 \%$ of the respondent invested less than USD 20 per season, depending on their land size as well as their financial status, for both purchasing seeds and any other needed materials. A total of $95 \%$ of the respondents received their technical advice from partners as shown in Figure 2.

\section{Financial aspects}

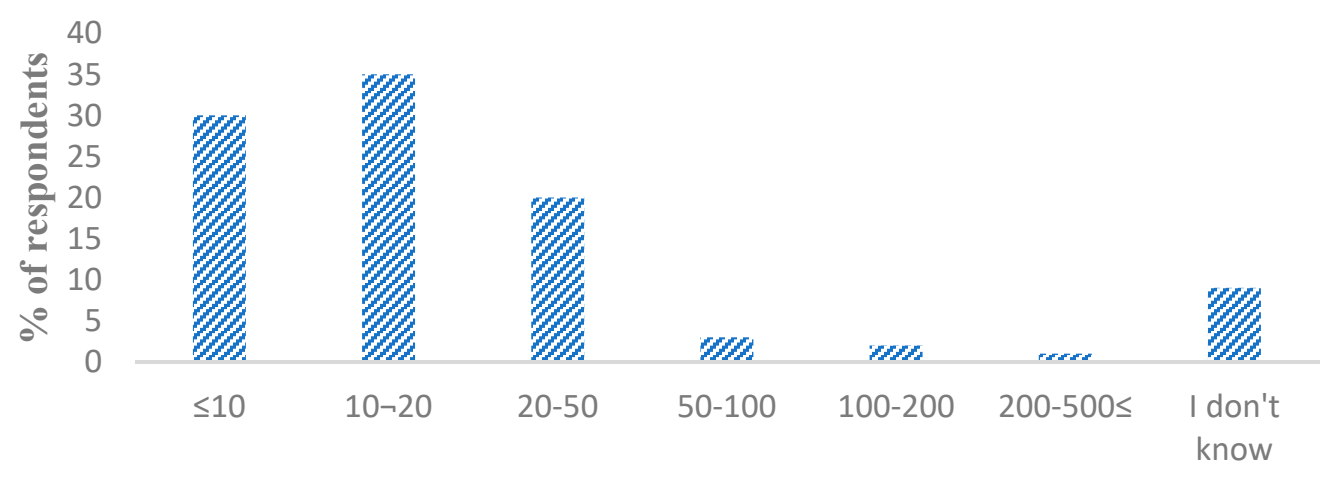

Amount of money in USD

Figure 2. Amount of money (in USD) invested into conservation agriculture farming $(n=500)$.

\subsection{Conservation Agriculture Knowledge}

This part describes the way respondents comprehended and practiced CA in the growing seasons; they briefed us about their CA practices and estimated their land portion under CA, community perceptions, benefits and constraints at the farm level, as well as what they perceived as important requirements for CA to be done by more members in their community.

Testing their level of understanding about CA practices, $85 \%$ of the respondents knew all three principles of $\mathrm{CA}$, although they were only able to apply two of these as required, i.e., crop rotation and minimum tillage. In turn, $10 \%$ of the respondents did not know well the three principles of CA, while $5 \%$ neither agreed nor disagreed that they knew all three principles. Nevertheless, they appreciated the skills gained from training as the most important factor that motivated them to adopt CA. In traditional farming practices, farmers till their land twice (the first and second tillage) before planting. The farmer's former practices were deep ploughing for the first tillage and pulverization for the second tillage, which lead to soil loosening, after which they sow or plant. With conservation tillage, rip lines are made into the land using hand hoes or small trees. To practice crop rotation, depending on what the farmers planted, they alternate the crops grown-either a legume or cereal different from the previous season. This rotation follows the rules and 
regulations of the crop intensification program by the ministry of agriculture and animal resources. With CA, the new crop combination has been tried introducing some cover crops with the main cash crop, which differ from traditional mono-cropping systems (planting only selected crops).

Regarding how often farmers practiced CA and the used size of land, all respondents practiced CA every season from 2016 to 2021, with variation in the size of the land used. Estimating the size of the land used, they said 3 terraces, 10 terraces, half or a quarter of their land. This gave an estimated total of 150 ha under CA per season held between the respondents that were interviewed.

Respondents' perceptions on why farmers in their region use CA were attributed to skills / knowledge and awareness of $\mathrm{CA}$ as a farming technique for farming $\left(\mathrm{CHI}^{2}=321.524\right.$; df. $=8 ; p=0.001 ;$ Cramer V = 0.813).

\section{Constraints Highlighted}

Farmers also have shown some of the constraints faced when practicing CA. There is a lack of follow-up and guiding by extension officers about materials, little interaction with extension officers, the need for further training and a lack of equipment. This affects negatively their agenda, the outcome as well as other farmers who would wish to join this type of technology. Other challenges included not getting enough cover crop varieties adapted to this place and the prices on the market, which are affected by middlemen who dictated the price of produce. A total of $60 \%$ of the respondents found CA easy to apply on their land, while $20 \%$ felt that it was not easy to apply. Overall, $48 \%$ agreed that they had enough knowledge to enable them to apply CA on their land, $28 \%$ stated increased yields as the main reason for practicing CA and $24 \%$ noted that their reason was because CA improved soil fertility as shown in Figure 3.

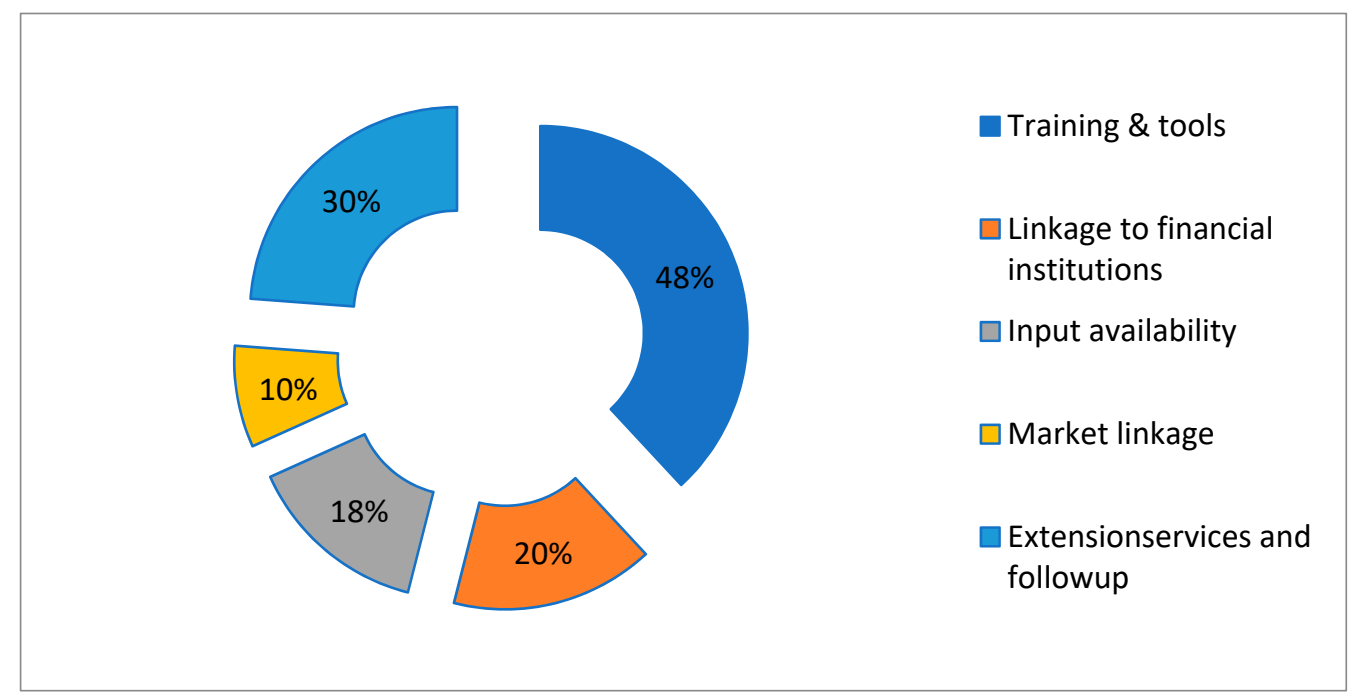

Figure 3. Farmer recommendations for increasing the adoption of conservation agriculture technol$\operatorname{ogy}(n=500)$.

Speeding up the adoption of CA in the region, most respondents suggested the provision of enough training, guidance and follow up, as well as providing tools.

\subsection{Social Factors}

The social factors that could influence the uptake of CA, such as land ownership, partners, group leader, group dynamics and technical training, among other factors, were also highlighted.

Close to $80 \%$ of the land was jointly owned by married couples, while $15 \%$ was owned by men and family land inherited from the man's or women's parents. Women owned only $5 \%$ of the land. Choosing the crops to plant in each season was made either jointly between 
the man and the woman or solely by the man. Few decisions (12\%) were made solely by the women as shown in Table 3.

Table 3. Social factors influencing conservation agriculture adoption by individuals.

\begin{tabular}{cc}
\hline Sociocultural Trait & \% Frequency $(\boldsymbol{n}=\mathbf{5 0 0})$ \\
\hline Personal decision & 90 \\
Group leader & 25 \\
Technical training & 80 \\
Technical aid & 41 \\
Cultural norms & 0 \\
Religious beliefs & 0 \\
Market demand & 90 \\
Land ownership & 50 \\
Group dynamics & 75 \\
Partner & 85 \\
\hline
\end{tabular}

The Pearson correlation of CA adoption and sociocultural factors in the communities where it was promoted was $r=0.326, p$-value $=0.000$. Briefly, the correlation indicates that the strength of association between the variables was low $(\mathrm{r}=0.326)$, and the correlation coefficient was significant $(p<0.000)$. It is also shown that $7 \%\left(0.326^{2}\right)$ of the variation in CA adoption is explained by sociocultural factors in the communities where it is implemented and promoted as shown in Table 4.

Table 4. Conservation agriculture adoption and social factors Pearson correlation test.

\begin{tabular}{cccc}
\hline \multicolumn{3}{c}{ Correlation } & \\
\hline & Adoption & Socio Factors \\
\hline & Pearson & 1 \\
correlation & $0.326^{* *}$ & \\
$\begin{array}{c}\text { Conservation agriculture } \\
\text { adoption }\end{array}$ & Sig. (Two tailed) & 00.000 & \\
& $\mathrm{~N}$ & 500 & $0.326^{* *}$ \\
& & \\
Sociocultural factors & Pearson & 1 & \\
& correlation & 0.0000 & \\
& Sig. & 500 & \\
\hline
\end{tabular}

** Correlation is significant at the 0.01 level (two tailed).

\subsection{Economic Factors}

Participants in this study estimated the amount of money they allocated in CA; they ranked the statements that could influence their adoption of this technology. Respondents made payments to buy seeds themselves and generally the profit expectations from increased yields motivated the farmers to take up CA as Table 5 shows. Most respondents were influenced by profit expectations, availability of a market, increased yields and available cash, and hardly relied on loans or even donations. They claimed that each household had its unique set of livelihood problems that necessitated them to sell their harvest whenever they felt the need, for instance, to send a child to school or access medical services for a sick household member. They sold their CA produce depending on these needs. 
Table 5. Description of the distribution of the answers related to the economic aspects of adoption.

\begin{tabular}{cc}
\hline Economic Related Factors & \% Frequency $(n=\mathbf{5 0 0})$ \\
\hline Increased yields & 90 \\
Profit expectations & 99 \\
Access to loans & 15 \\
Input availability & 20 \\
Cash at hand & 80 \\
Prices on market & 65 \\
Market availability & 70 \\
Social trust & 40 \\
Youth and women involvement & 35 \\
Donations & 38 \\
Group negotiations & 35 \\
\hline
\end{tabular}

\subsection{Institutional Factors}

Factors related to the institutions involved in this type of agriculture required information on government programs, partners promoting CA in the district and extension services are described in Table 6.

Table 6. Description of the distribution of the answers related to institutions regarding conservation agriculture adoption.

\begin{tabular}{cc}
\hline Institutions Related Factors & \% Frequency $(\boldsymbol{n}=\mathbf{5 0 0})$ \\
\hline Government agencies promoting conservation agriculture & 10 \\
NGOs promoting conservation agriculture & 80 \\
Government communication on conservation agriculture & 10 \\
Traditional practices encouraging conservation agriculture adoption & 60 \\
Government responsibility on conservation agriculture performance & 5 \\
Conducive political environment & 95 \\
Government programs on conservation agriculture & 10 \\
\hline
\end{tabular}

Respondents in this study estimated the factors related to institutions; they ranked statements concerning NGOs and government programs that have influenced their adoption of this technology. NGOs have shown the lead in this type of agriculture where $80 \%$ of the respondents said they acquired CA skills from them; traditional farming practices with the same components as CA encouraged and scaled up the adoption of the technology as well $(60 \%)$. The results show little evidence of government involvement and commitment to $\mathrm{CA}$ in the area. Apart from the conducive environment, there is no other program, promotion, follow up and evaluation of this technology.

\section{Discussion}

Conservation agriculture adoption in the Gicumbi district, with its high number of smallholder farmers, showed promising expectations for adopting and improving effective strategies for developing this technology. As each part may have its specific context, it needs a sole understanding of what might work to achieve the required responses in different regions. The study has proven the positive adoption of CA in districts such as Gicumbi in northern Rwanda. Gicumbi experiences increasing vulnerability to adverse weather conditions related to climate change, perverse poverty, historical inequalities besides its remoteness and other related effects.

The main causes that pushed adoption of CA in this part of the country was due to the information gained through training provided by the Transformational Leadership Centre (TLC) and Mennonite Central Committee (MCC), NGOs. This proves that getting information was the driving force for adopting CA technology. The training received was different as it involved technical information and hands on work, which helped farmers know why and how to practice $\mathrm{CA}$, and thus not just giving instructions and reading 
materials. The farmers grasped the technical information about CA, thus providing a contrast with other findings and suggesting that CA knowledge was too complicated a package for ordinary rural small-scale farmers to understand. The results showed that it was about providing learning opportunities and exposure to people to enable technology uptake. This is similar to the adoption of this CA technology in Uganda [49] and Kenya [50].

Northern Rwanda farming systems are characterized by annual cereals, legumes, tubers and cattle rearing. Subsistence farming systems still exist there where farmers only sell the surplus to the market. This shows an attempt at striking a balance between providing food for their households and earning an income.

The investments allocated to CA activities reflect poverty in this region. The farmers' savings groups, commonly called IBIMINA, offered group accountability and generally meant lower risks of loss of capital assets in the case of a failure to repay loans. Farmers could hardly afford mainstream financial institutions, such as banks. Poor infrastructure and lack of easy public transport meant that most services were out of reach for these farmers. This implied high transportation costs and, perhaps, the encouragement of middlemen to take advantage of the situation. It is worth noting that Rwanda has a high cost of credit, ranking 84th out of 137 countries in affordability of financial services [51]. These factors imply that there is a high financial barrier for smallholder farmers that need to be addressed. Development and promotion of CA in the Gicumbi district would require better financial investment, as the work of Sims and Heney [52] explicitly showed.

Social factors dealt with in the study seem to be supportive of CA uptake. Social issues are already known to be useful in changing attitudes and gradually causing a shift away from conventional agriculture over time. Government support and incentive programs could certainly be used in this region to effectively increase further adoption in the region; for instance, in providing access to training, follow up, tools, social learning, social development and other social benefits. Further empirical studies are needed to further explore the role of social networks in the adoption of CA in similar areas and which social factors are at play in the region. Land-access rights, particularly for women and the youth, need to be further explored [49].

The economic perspective looked at showed that there is still a need for motivation towards CA adoption, such as the gain in profits from the extra produce that normally arise from applying the technology. For farmers to benefit from market prices, they would need to improve their group negotiation power, as opposed to letting middlemen take advantage of them. However, given the high poverty levels and heterogeneity of households, exploitation by middlemen is a risk unless there is market regulation through government and private-sector engagement. To add value at the village level, other actions, such as agro processing plants, etc., have the potential to increase farmers' selling options and prices for their harvest. These small-income increments could further motivate the adoption [53].

Lastly, there is a need of more involvement of government and other related institutions in CA technology development and promotion. The adoption pattern would be a good opportunity for the government to show its commitment to the rural farmers of this region through, for instance, supporting CA scaling-up, as said before. Improving extension services would bring a considerable change in adopting this technology. In addition to limited coordination and coverage of extension services, the subsidized scheme of the crop intensification program is not keen on developing this technology and assisting in the inputs used in it. The government and different NGOs in agriculture would have to promote CA in the region as there could possibly be positive effects in the socioeconomic and environmental development of the region, such as the reduced erosion, increased yields and income and climate change adaptation with a wide adoption of CA [53,54].

The fact that this study used descriptive data for exploratory analysis without considering causal factors, means it should be sustained by additional quantitative further studies. 


\section{Conclusions}

This study objective was to characterize the CA adopters in the Gicumbi district region of Rwanda. The socioeconomic status of the farmers, demography, farming practices, institutional factors and suggestions of the relevant strategies for its wide adoption were studied. The experiences and views of the farmers on the appropriateness and impact of CA within their contexts were described. The data captured from the respondents estimated the use of CA on their land, the frequency of use and their individual reasons for adopting it, as well as the constraints. Other factors looked at included the economic and social factors, to form a background for further promotion of CA in the region and other parts of the country.

Adoption of CA in the Gicumbi district is likely to happen and can be built on to make it viable and highly profitable. Awareness, training, extension and financial services accessibility, as well as social incentives and government program support are seen as motivators with regard to CA adoption, as discussed above. The Gicumbi district socioeconomic and environmental status would be improved by improving farming practices, improving the financial services accessibility that influence the money invested in CA technology and increasing the extension services and follow up for increased adoption and frequency of practicing CA. Socioeconomic issues, such as land ownership, farming group dynamics, financial access and control, need to be discussed and solved before the faming season starts, as they impact CA adoption. Providing the related training, specific programs, enough extension services tools and follow up would be an opportunity for institutions and policy makers to partner with farmers to promote this technology. From this, farmers will take advantage of CA and eventually intensify it. Moreover, there is a need to do more research on yields, production cost, gender issues, land ownership issues, produce markets and soil quality improvement for this technology to look more attractive. The described data in this research will form a foundation for upscaling the technology in this district as well as other parts of the country.

Author Contributions: Conceiving, designing, writing and carrying out the fieldwork done by Y.T.M.; M.K. and P.K. supervised the work. All authors have read and agreed to the published version of the manuscript.

Funding: This research received no external funding.

Data Availability Statement: Not applicable.

Conflicts of Interest: The authors declare no conflict of interest.

\section{References}

1. National Institute of Statistics of Rwanda. Rwanda Fourth Population and Housing Census. In Thematic Report: Population Size, Structure and Distribution; National Institute of Statistics of Rwanda: Kigali, Rwanda, 2012.

2. National Institute of Statistics of Rwanda. Rwanda Demographic and Health Survey 2014-15; NISR, MOH, and ICF International: Rockville, MD, USA; National Institute of Statistics of Rwanda: Kigali, Rwanda, 2015.

3. National Institute of Statistics of Rwanda. GDP National Accounts, 2016. In Rebased estimates of GDP: An Explanatory Note; National Institute of Statistics of Rwanda: Kigali, Rwanda, 2017.

4. Cantore, N. The Crop Intensification Program in Rwanda: A Sustainability Analysis; Overseas Development Institute: London, UK, 2011.

5. National Institute of Statistics of Rwanda. EICV4-Economic Activity Thematic Report; National Institute of Statistics of Rwanda: Kigali, Rwanda, 2016.

6. Boserup, E. The Conditions of Agricultural Growth: The Economics of Agrarian Change under Population Pressure; Transaction Publishers: Piscataway, NJ, USA, 2005.

7. Kelly, V.; Mpyisi, E.; Shingiro, E.; Nyarwaya, J.B. Agricultural Intensification in Rwanda: An Elusive Goal. In Food Security Research Project/Division of Agricultural Statistics Policy Brief; Ministry of Agriculture, Animal Resources and Forestry: Kigali, Rwanda, 2001.

8. Kagabo, D.M.; Stroosnijder, L.; Visser, S.M.; Moore, D. Soil erosion, soil fertility and crop yield on slow-forming terraces in the highlands of Buberuka, Rwanda. Soil till. Res. 2013, 128, 23-29. [CrossRef]

9. Nambajimana, J.D.; Xiubin, H.; Zhou, J.; Meta, F.J.; Jinlin, L.; Khurram, D.; Mind'je, R.; Nsabimana, G. Land Use Change Impacts on Water Erosion in Rwanda. Sustainability 2020, 12, 50. [CrossRef] 
10. Bryan, E.C.; Okoba, B.; Roncoli, C.; Silvestri, S.; Herrero, M. Adapting agriculture to climate change in Kenya: Household strategies and determinants. J. Environ. Manag. 2013, 114, 26-35. [CrossRef] [PubMed]

11. Below, T.; Artner, A.; Siebert, R.; Sieber, S. Micro-level practices to adapt to climate change for African small-scale farmers. Rev. Sel. Lit. 2010, 953, 1-20.

12. Lybbert, T.J.; Sumner, D.A. Agricultural technologies for climate change in developing countries: Policy options for innovation and technology diffusion. Food Policy 2012, 37, 114-123. [CrossRef]

13. Rwanyiziri, G.; Rugema, J. Climate Change Effects on Food Security in Rwanda: Case Study of Wetland Rice Production in Bugesera District. Rwanda J. 2013, 1, 35-51.

14. MINAGRI. Crop Intensification Program; Ministry of Agriculture and Livestock: Kigali, Rwanda, 2007. Available online: https: / / rab.gov.rw /index.php?id=188 (accessed on 25 July 2021).

15. MINAGRI. Strategic Plan for the Transformation of Agriculture in Rwanda Phase III (2018-2024); Ministry of Agriculture and Livestock: Kigali, Rwanda, 2017. Available online: rwa180543.pdf (accessed on 26 July 2021).

16. MINAGRI. National Agriculture Policy, Kigali: Ministry of Agriculture and Animal Resources; Ministry of Agriculture and Livestock: Kigali, Rwanda, 2018. Available online: https://www.minagri.gov.rw/fileadmin/user_upload/Minagri/Publications/Policies_ and_strategies/National_Agriculture_Policy_-_2018__Approved_by_Cabinet.pdf (accessed on 20 July 2021).

17. Food and Agriculture Organization (FAO). Conservation Agriculture. Available online: www.fao.org/conservation-agriculture/ en/ (accessed on 28 July 2021).

18. Giller, K.E.; Corbeels, M.; Nyamangara, J.; Triomphe, B.; Affholder, F.; Scopel, E.; Tittonell, P. A research agenda to explore the role of conservation agriculture in African smallholder farming systems. Field Crop. Res. 2011, 124, 468-472. [CrossRef]

19. Rusinamhodzi, L.; Corbeels, M.; van Wijk, M.T.; Rufino, M.C.; Nyamangara, J.; Giller, K.E. A meta-analysis of long-term effects of conservation agriculture on maize grain yield under rain-fed conditions. Agron. Sustain. Dev. 2011, 31, 657-673. [CrossRef]

20. Hobbs, P.R.; Govaerts, B. How conservation agriculture can contribute to buffering climate change. Clim. Chang. Crop. Prod. 2010, $1,177-199$.

21. Verdoodt, A.; Van Ranst, E. Land Evaluation for Agricultural Production in the Tropics. A Large-Scale Land Suitability Classification for Rwanda; Laboratory of Soil Science, Ghent University: Ghent, Belgium, 2003.

22. Mubiru, D.N.; Namakula, J.; Lwasa, J.; Otim, G.A.; Kashagama, J.; Nakafeero, M.; Nanyeenya, W.; Coyne, M.S. Conservation Farming and Changing Climate: More Beneficial than Conventional Methods for Degraded Ugandan Soils. Sustainability 2017, 9, 1084. [CrossRef]

23. Hobbs, P.R.; Sayre, K.; Gupta, R. The role of conservation agriculture in sustainable agriculture. Philos. Trans. R. Soc. Lond. B Biol. Sci. 2008, 363, 543-555. [CrossRef]

24. Vaiknoras, K.; Norton, G.; Alwang, J.R.; Taylor, D. Preferences for Attributes of Conservation Agriculture in Eastern Uganda. In Proceedings of the 2014 Annual Meeting, Agricultural and Applied Economics Association, Minneapolis, MN, USA, 27-29 July 2014.

25. Friedrich, T.; Derpsch, R.; Kassam, A. Overview of the Global Spread of Conservation Agriculture. Field Actions Sci. Rep. 2012, 6, 1941.

26. Kassam, A.H.; Mkomwa, S.; Friedrich, T. Conservation Agriculture for AFRICA: Building Resilient Farming Systems in a Changing Climate; CABI: Wallingford, UK, 2017.

27. Andersson, J.A.; D'Souza, S. From adoption claims to understanding farmers and contexts: A literature review of Conservation Agriculture (CA) adoption among smallholder farmers in southern Africa. Agric. Ecosyst. Environ. 2014, 187, 116-132. [CrossRef]

28. Nicol, A.; Langan, S.; Victor, M.; Gonsalves, J. Water-Smart Agriculture in East Africa; IWMI: Colombo, Sri Lanka, 2015.

29. Baudron, F.; Sims, B.; Justice, S.; Kahan, D.G.; Rose, R.; Mkomwa, S.; Kaumbutho, P.; Sariah, J.; Nazare, R.; Moges, G.; et al. Re-examining appropriate mechanization in Eastern and Southern Africa: Two-wheel tractors, conservation agriculture, and private sector involvement. Food Secur. 2015, 7, 889-904. [CrossRef]

30. Thierfelder, C.; Matemba-Mutasa, R.; Bunderson, W.T.; Mutenje, M.; Nyagumbo, I.; Mupangwa, W. Evaluating manual conservation agriculture systems in southern Africa. Agric. Ecosyst. Environ. 2016, 222, 112-124. [CrossRef]

31. Thierfelder, C.; Bunderson, W.T.; Jere, Z.D.; Mutenje, M.; Ngwira, A. Development of conservation agriculture (CA) systems in Malawi: Lessons learned from 2005 to 2014. Exp. Agric. 2016, 52, 579-604. [CrossRef]

32. Corbeels, M.; Graaff, D.J.; Hycenth Ndah, T.; Penot, E.; Bauon, F.; Naudin, K.; Anieu, N.; Chirat, G.; Schuler, J.; Nyagumbo, I.; et al. Understanding the impact and adoption of conservation agriculture in Africa: A multi-scale analysis. Agric. Ecosyst. Environ. 2014, 187, 155-170. [CrossRef]

33. Giller, K.E.; Andersson, J.A.; Corbeels, M.; Kirkegaard, J.; Mortensen, D.; Erenstein, O.; Vanlauwe, B. Beyond conservation agriculture. Front. Plant Sci. 2015, 6, 870. [CrossRef]

34. Giller, K.E.; Witter, E.; Corbeels, M.; Tittonell, P. Conservation agriculture and smallholder farming in Africa: The heretics' view. Field Crops Res. 2009, 114, 23-34. [CrossRef]

35. Rusinamhodzi, L. Tinkering on the periphery: Labour burden not crop productivity increased under no-till planting basins on smallholder farms in Murehwa district, Zimbabwe. Field Crops Res. 2015, 170, 66-75. [CrossRef]

36. Baudron, F.; Andersson, J.A.; Corbeels, M.; Giller, K.E. Failing to Yield? Ploughs, Conservation Agriculture and the Problem of Agricultural Intensification: An Example from the Zambezi Valley, Zimbabwe. J. Dev. Stud. 2012, 48, 393-412. [CrossRef] 
37. Nkala, P. Assessing the Impacts of Conservation Agriculture on Farmer Livelihoods in Three Selected Communities in Central Mozambique; University of Natural Resources and Life Science: Vienna, Austria, 2012.

38. Brouder, S.M.; Gomez-Macpherson, H. The impact of conservation agriculture on smallholder agricultural yields: A scoping review of the evidence. Agric. Ecosyst. Environ. 2014, 187, 11-32. [CrossRef]

39. Kassie, M.; Teklewold, H.; Jaleta, M.; Marenya, P.; Erenstein, O. Understanding the adoption of a portfolio of sustainable intensification practices in eastern and southern Africa. Land Use Policy 2015, 42, 400-411. [CrossRef]

40. Brown, B.; Nuberg, I.; Llewellyn, R. Further participatory adaptation is required for community leaders to champion conservation agriculture in Africa. Int. J. Agric. Sustain. 2018, 16, 286-296. [CrossRef]

41. Bell, A.R.; Cheek, J.Z.; Mataya, F.; Ward, P.S. Do as They Did: Peer Effects Explain Adoption of Conservation Agriculture in Malawi. Water 2018, 10, 51. [CrossRef]

42. Ngwira, A.; Johnsen, F.H.; Aune, J.B.; Mekuria, M.; Thierfelder, C. Adoption and extent of conservation agriculture practices among smallholder farmers in Malawi. J. Soil Water Conserv. 2014, 69, 107-119. [CrossRef]

43. Farooq, M.; Siddique, K.H.M. Conservation Agriculture; Springer: Berlin, Germany, 2016.

44. National Institute of Statistics of Rwanda. Rwanda third Population and Housing Census; EICV 3District Profile: Gicumbi, Rwanda, 2012. Available online: https:// statistics.gov.rw/publication/eicv-3-gicumbi-district-profile (accessed on 22 July 2021 ).

45. Ellard-Gray, A.; Jeffrey, N.K.; Choubak, M.; Crann, S.E. Finding the Hidden Participant: Solutions for Recruiting Hidden, Hard-to-Reach, and vulnerable populations. Int. J. Qual. Methods 2015, 14. [CrossRef]

46. Gicumbi District. Water Resources Management Plan for the Water Sources and Mwange River Watershed in Gicumbi District. 2018. Available online: https://www.washagendaforchange.org/wp-content/uploads/2020/04/water_sources_management_ plan_in_gicumbi_-_report_-_sep_2018.pdf (accessed on 30 June 2021).

47. Schut, M.; Klerkx, L.; Rodenburg, J.; Kayeke, J.; Hinnou, L.C.; Raboanarielina, C.M.; Adegbola, P.Y.; van Ast, A.; Bastiaans, L. RAAIS: Rapid Appraisal of Agricultural Innovation Systems (Part I). A diagnostic tool for integrated analysis of complex problems and innovation capacity. Agric. Syst. 2015, 132, 1-11. [CrossRef]

48. Schut, M.; Rodenburg, J.; Klerkx, L.; Kayeke, J.; van Ast, A.; Bastiaans, L. RAAIS: Rapid Appraisal of Agricultural Innovation Systems (Part II). Integrated analysis of parasitic weed problems in rice in Tanzania. Agric. Syst. 2015, 132, 12-24. [CrossRef]

49. Kaweesa, S.; Mkomwa, S.; Loiskandl, W. Adoption of Conservation Agriculture in Uganda: A Case Study of the Lango Subregion. Sustainability 2018, 10, 3375. [CrossRef]

50. Wangithi, C.M.; Muriithi, B.W.; Belmin, R. Adoption and Dis-Adoption of Sustainable Agriculture: A Case of Farmers' Innovations and Integrated Fruit Fly Management in Kenya. Agriculture 2021, 11, 338. [CrossRef]

51. Schwab, K. The Global Competitiveness Report 2017-2018; World Economic Forum: Geneva, Switzerland, 2017 ; p. 251.

52. Sims, B.; Heney, J. Promoting Smallholder Adoption of Conservation Agriculture through Mechanization Services. Agriculture 2017, 7, 64. [CrossRef]

53. Serebrennikov, D.; Thorne, F.; Kallas, Z.; McCarthy, S.N. Factors Influencing Adoption of Sustainable Farming Practices in Europe: A Systemic Review of Empirical Literature. Sustainability 2020, 12, 9719. [CrossRef]

54. Kabirigi, M.; Musana, B.; Ngetich, F.; Mugwe, J.; Mukuralinda, A.; Nabahungu, N.L. Applicability of conservation agriculture for climate change adaptation in Rwanda's situation. J. Soil Sci. Environ. Manag. 2015, 6, 241-248. 